\title{
Bacteriological and Histopathological Evaluation of Articulations of Chickens Diagnosed with Arthritis
}

\section{-Author(s)}

Marcon AV' (iD https://orcid.org/0000-0002-9147-9410 De Oliveira GF' (iD https://orcid.org/0000-0002-4591-037X Caldara FR' (iD https://orcid.org/0000-0002-7564-6127 Garcia RG' (iD) https://orcid.org/0000-0002-4978-9386 Matins RA' (iD) https://orcid.org/0000-0001-7681-1983 Marcon A' (D) https://orcid.org/0000-0002-5237-6486 Crone Cl (iD) https://orcid.org/0000-0003-3422-1613 Assunción ASA' (iD) https://orcid.org/0000-0001-9175-9917

College of Agrarian Sciences. Federal University of Grande Dourados. Dourados, Brasil.

" Caxias do Sul University. Caxias do Sul, Brasil.

\section{-Mail Address}

Corresponding author e-mail address Geyssane Oliveira

Rua José Barbosa de Barros, 1630, Jardim Paraíso, Botucatu, São Paulo, Brasil, 16610307

Phone: (5567) 9 9826-5279

Email: geyssanesousa@hotmail.com

\section{-Keywords}

Infectious, inflammatory, public health Staphylococcus aureus.

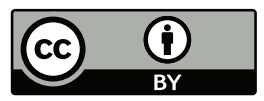

Submitted: 06/November/2018 Approved: 17/Mach/2019

\section{ABSTRAT}

Arthritis implies inflammation of the intra-articular structures and is one of the causes of condemnation in broilers. The disease is associated with infectious agents such as Staphylococcus aureus, which may pose a potential public health risk. This work was conducted with the objective to determine the occurrence of arthritis in broiler chickens, predominantly of bacterial staphylococcal origin and if there is a difference between the degrees of injury regarding the presence of the bacterium and the histological lesion. Sixty samples of chickens diagnosed with arthritis by Federal Inspection Service from commercial slaughterhouse were collected according to their severity (of mild and severe degree) and submitted to bacteriological and histopathological analysis. There was bacterial growth of Staphylococcus aureus in 3.3\% of the samples classified as mild degree in $10 \%$ of the samples classified as severe grade of lesion $(p=0,29)$. For histopathological evaluation, $16.67 \%$ and $70 \%$ of the samples presented inflammatory infiltrate in mild and severe degrees, respectively $(p=0,0001)$. Mild degree arthritis is related to non-infectious lesions in their higher prevalence while severe-grade arthritis has infectious causes. The condemnation criteria were efficient since $S$. aureus could be present regardless of the degree of the lesion diagnosed in arthritis.

\section{INTRODUCTION}

Locomotive disorders can be classified according to the underlying pathology as infectious, developmental and degenerative. Infectious disorders are related to necrosis of the femur head of bacterial origin, tenosynovitis, arthritis, and virus-induced neoplasia. There are numerous causes that lead to skeletal deformities in chickens, such as nutritional, genetic, pathogenic and management practices hampering the growth and development of poultry (Cook, 2000).

Infectious arthritis in broilers is of paramount importance because it causes economic losses of great impact due to the reduction of productivity, besides representing a sanitary problem (Reck et al., 2012) and is one of the main causes of condemnation of birds in slaughterhouses (Moura etal. 2012; Oliveira etal., 2016). Staphylococcus aureus is known to cause septic arthritis in poultry with significant economic losses and may pose a potential public health risk (Nazia et al., 2015). This agent has high affinity for collagen-rich surfaces, such as the articular surfaces of joints, and synovial sheaths around joints and tendons (Joiner et al., 2005). Arthritis or polyarthritis is defined in the condemnation as swelling of one (arthritis) or both (polyarthritis) of the knees (Lupo et al., 2008).

Meat sanitary inspection aims to protect public health by ensuring that minimal hazardous material enters in the food chain through carcasses rejected (Huneau-Salaun et al., 2015). 
Marcon AV, De Oliveira GF, Caldara FR, Garcia RG, Matins RA, Marcon A, Crone C, Assunción A
Bacteriological and Histopathological Evaluation of Articulations of Chickens Diagnosed with Arthritis
These carcasses, which are rejected as unfit for human consumption, are detected on the basis of macroscopic visual criteria and the condemnation operation is the responsibility and under the supervision of the official veterinary services (Lupo et al., 2008). The identification of the etiological agents involved in the infectious arthritis facilitates preventive and control measures in the farms to reduce this pathology, avoiding economic losses due to the partial or total condemnation of the carcasses in the slaughterhouses (Costa et al., 2016).

The aim of this study was to verify if the occurrence of arthritis in broilers is predominantly of bacterial staphylococcal origin and if there is a difference between the degrees of macroscopic lesion as to the presence of the bacterium and the histological lesion, thus providing subsidies to those involved in the work inspection.

\section{MATERIAL AND METHODS}

The study was conducted in a commercial slaughterhouse in the state of Santa Catarina, with a daily slaughter of 180.000 broilers/day 60 broiler carcass samples with partial arthritic condemnation were used, in which the evaluation and condemnation of the carcasses were carried out by the Federal Inspection Service in accordance with the criteria for carcass condemnation of poultry established by brazilian legislation (Brasil, 1998). The carcasses samples were collected from slaughtered broilers with 32 days of age and an average weight of $1.5 \mathrm{~kg}$ with macroscopic alterations in condemned tibiotarsial joints.

The birds were electrically stunned $(50 \mathrm{~Hz}, 100 \mathrm{~mA}$ for $12 \mathrm{~s})$, bled out, scalded $\left(60.5^{\circ} \mathrm{C}, 2 \mathrm{~min}\right)$, plucked, gutted automatically and picked in the federal inspection department (DIF). Each sample consisted of a single leg, classified by macroscopic changes, staining and volume of the lesion as described in table 1, after condemnation of the sanitary inspection (Barcelos et al., 2006).

Table 1 - Classification macroscopic of the lesions of arthritis.

\begin{tabular}{lcc}
\hline & Staining & Volume \\
\hline Mild degree lesion & Light red & low volume \\
Severe degree lesion & Dark red to greenish color & increased volume \\
\hline
\end{tabular}

The legs were stored in identified sterile bags and kept refrigerated $\left(2\right.$ to $\left.8^{\circ} \mathrm{C}\right)$ in thermal boxes for a maximum period of 24 hours.
The bacteriological and histopathological analyzes were performed at the Mercolab laboratory (Cascavel $P R)$. For bacteriological evaluation, the external surface of the joint was flamed, performing a cut above the joint and collecting with a swab for determination of Staphylococcus aureus. The swab was scored on blood agar plates. The already seeded plates were incubated inverted in a bacteriological oven at $37^{\circ} \mathrm{C}$ for 24-48 hours (Quinn et al., 2005). The plaques that presented bacterial growth were smeared on glass slides for microscopy and stained for verification of the morphotintorial characteristics by the Gram method (Quinn et al., 2005). The biochemical test of catalase was carried out from the colonies. After that, the biochemical tests were read and interpreted according to (Quinn et al., 2005).

The epidermis, articular capsule, tendons and adjacent tissues were collected for histopathological processing. The samples were fixed in $10 \%$ buffered formalin solution, included in liquid paraffin, then cut into a microtome $(5 \mu \mathrm{m})$, stained with hematoxylin and eosin ( $H \& E$ ), and finally analyzed by an optical microscope (McManus \& Mowry, 1965).

For the statistical analysis, the frequency of positive tests in the bacteriological and histopathological studies in relation to the total of samples tested was analyzed by the binary logistic regression test using Minitab software version 17.3.

\section{RESULTS AND DISCUSSION}

Of the 60 samples analyzed, there was bacterial growth for Staphylococcus aureus in 3.3\% of the mild degree and $10 \%$ in the severe degree. There was no difference for $\mathrm{S}$. aureus growth between the samples classified in mild and severe degree arthritis $(p=0.29)$ (Table 2). However, lesions and heterophilic inflammatory infiltrates in the histopathological analyzes were significantly higher $(p=0.0001)$ in the samples classified as severe degree arthritis (Table 2).

Table 2 - Binary logistic regression of number and percentage (\%) of positive samples for bacterial growth and histopathological changes in arthritis samples diagnosed by sanitary inspection.

\begin{tabular}{lccccc}
\hline & \multicolumn{1}{c}{ Mild degree lesion } & \multicolumn{2}{c}{ Severe degree lesion } & Value - P \\
\hline & $\mathrm{N}$ & $\%$ & $\mathrm{~N}$ & $\%$ & \\
\hline Bacteriological & 1 & $3.3 \%$ & 3 & $10.0 \%$ & 0,29 \\
Histopathological & 5 & $16.67 \%$ & 21 & $70.00 \%$ & 0,0001 \\
\hline
\end{tabular}

The prevalence of $\mathrm{S}$. aureus in the present study concur with Tsai et al. 2015, in which 15,5\% isolates 
Marcon AV, De Oliveira GF, Caldara FR, Garcia RG, Matins RA, Marcon A, Crone C, Assunción A
Bacteriological and Histopathological Evaluation of Articulations of Chickens Diagnosed with Arthritis from the arthritic joint of chicken were identified as S. aureus collected from chicken. However, it was lower than in previous studies varying according to the study. Rasheed (2011) and Joiner et al. (2005) detected isolates of S. aureus in $50.98 \%$ and $45,3 \%$ respectively from broilers with arthritis. Kibenge et al. (1982) and Nazia et al. (2015) reported that S. aureus was recovered in about $70 \%$ of the tendon fluid samples examined with macroscopic changes and hock joints, respectively. In animals, as in humans, S. aureus is found even in healthy carriers, and can induce a broad panel of infections ranging from superficial, such as mild to severe arthritis to deep infections and septicemia Peton \& Le Loir (2014)

Table 3 - Histopathological features present in arthritic lesions diagnosed by Federal Inspection Service.

\begin{tabular}{lcc}
\hline Lesion characteristics & $\begin{array}{c}\text { Mild } \\
\text { level }\end{array}$ & $\begin{array}{c}\text { Severe } \\
\text { Level }\end{array}$ \\
\cline { 2 - 3 } & $\begin{array}{c}\text { Number of } \\
\text { samples }\end{array}$ & $\begin{array}{c}\text { Number of } \\
\text { Samples }\end{array}$ \\
\hline Absence of significant lesions and infiltration & 25 & 9 \\
Discrete heterophilic inflammatory infiltrate & 2 & 9 \\
Moderate heterophilic inflammatory infiltrate & 3 & 5 \\
Intense heterophilic inflammatory infiltrate & 0 & 5 \\
Severe heterophilic inflammatory infiltrate & 0 & 2 \\
\hline
\end{tabular}

Table 3 shows the distribution of the characteristics of the lesions present in articulations diagnosed with arthritis and Figure 1 shows the histopathological findings. All samples that were positive for $\mathrm{S}$. aureus in the bacteriological study also had heterophilic inflammatory infiltrate, which confirms according to Daum et al. (1990) that septic arthritis is defined bacteriologically when $\mathrm{S}$. aureus is isolated from the synovial surface and when heterophilic infiltrates are present in the synovial surface.

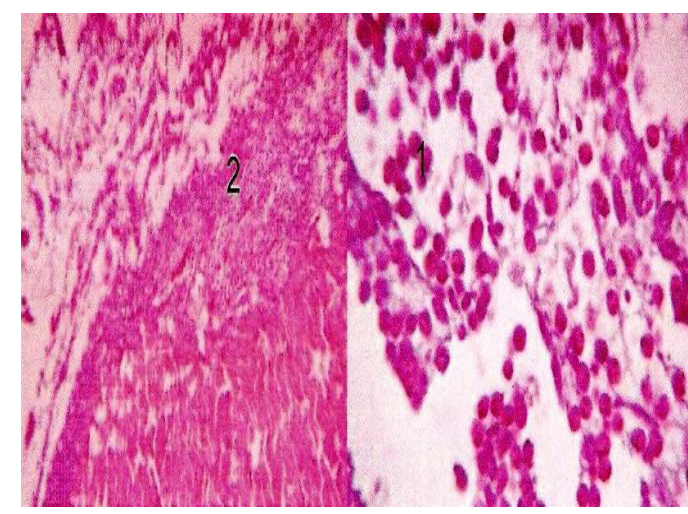

Figure 1 - Peritendent area presenting mild (1) moderate (2) heterophilic inflammatory infiltrate.

The histological result of the severe degree samples agrees with the findings of Tsai et al. (2015) which detected alterations of heterophilic infiltration of the synovial membrane, synovial fold, and tendon collagen in half of the arthritic cases. As in this study, Joiner et al. (2005) demonstrated the histomorphologic criteria confirmed for staphylococcal osteomyelitis and tenosynovitis of the lame chickens that had either negative bacterial cultures and / or no significant gross lesions.

The positive histopathological result along with the bacteriological absence may suggest that an infection by another etiological agent that was not detected in the bacteriological examination may have thus prompted a type of heterophilic inflammatory response in articulations with arthritis in severe degrees. It is hypothesized that arthritis and tenosynovitis may also be due to an early viral infection that usually remains subclinical and that secondary infection with bacteria, particularly S. aureus, may be responsible for the development of clinical signs (Kibenge et al.,1982). Arthritis is also predisposed by infectious agents such as Reovirus (artrotropic) or Mycoplasma synoviae. This would justify the absence of bacteriological positivity. These agents have already been recovered from chicken tendon tissue with a concomitant bacterial infection. Although the pathology observed in chickens clinically affected is suggestive of a bacterial etiology (Kibenge et al., 1982; Whitehead, 1992).

An absence of infectious agents is still possible, as Carlton \& McGavin (1998) reported that sterile lesions of the articular cartilage may be a consequence of trauma, since the articular cartilage and the subchondral bone deform under pressure and the synovial membrane may respond to aggression by hypertrophy and hyperplasia of villi and lining cells. The mild injuries could be caused by traumas associated with rapid growth rates of modern chickens and thus not infectious (Julian, 1998, 2005). Tendon ruptures due to over weight results in damaging the affected part in the processing be cause the tip of the ruptured tendon exhibits grossly visible hemorrhage macroscopically with red, blue or green coloration on the tissue above the knee (Julian, 2005).

\section{CONCLUSION}

The mild lesions due to the low incidence of heterophilic and bacteriological infiltrates are noninfectious in their higher prevalence. The condemnation criteria was efficient, discarding legs with potential risk of transmission of diseases for consumers since $\mathrm{S}$. aureus could be present regardless of the degree of the lesion diagnosed in arthritis. 
Marcon AV, De Oliveira GF, Caldara FR, Garcia RG, Matins RA, Marcon A, Crone C, Assunción A

\section{REFERENCES}

Barcelos AS, Flores ML, Kommers GD, Nascimento VP, Segabinazi SD, et al. Macroscopy, histopathology and bacteriology of livers of chickens (Gallus gallus) condemned at slaughter. Ciência Rural 2006;36(2):561567.

Brasil. Portaria n.210, de 10 de novembro de 1998. Regulamento técnico da inspeção tecnológico e higiênico-sanitária de carne de aves. Brasília; 1998. Available from: http://www.cidasc.sc.gov.br/inspecao/ files/2012/08/port-210.pdf

Carlton WW, McGavin MD. Thomson special veterinary pathology. $2^{\text {nd }}$ ed. Porto Alegre: Artmed;1998.

Cook ME. Skeletal deformities and their causes: introduction. Poultry Science 2000;79:982-984

Costa DR, Santana ES, Coelho KO. Infectious arthritis in broiler chickens. Enciclopédia Biosfera 2016;13(24):87

Daum RS, Hodges DW, Barton FK, Campeau RJ, Mulvihill, DM, Shane SM. A model of Staphylococcus aureus bacteremia, septic arthritis, and osteomyelitis in chickens. Journal of Orthopaedic Research $1990 ; 8(6): 804-813$

Huneau-Salaun A, Stark AKDC, Mateus A, Lupo C, Linderberg A, et al. Contribution of Meat Inspection to the surveillance of poultryhealth and welfare in the European Union. Epidemiology Infection 2015;143: 2459-2472.

Julian RJ. Production and growth related disorders and other metabolic diseases of poultry - A review. The Veterinary Journal 2005;169(3):350369.

Julian RJ. Rapid growth problems: ascites and skeletal deformities in broilers. Poultry Science 1998;77(12):1773-1780.

Joiner KS, Hoerr FJ, Santen E, Ewald SJ. The avian major histocompatibility complex influences bacterial skeletal disease in broiler breeder chickens, Veterinary Pathology 2005;42:275-281.

Kibenge FSB, Robertson MD, WilcoxGE,Pass DA. Bacterial and viral agents associated with tenosynovitis in broiler breeders in Western Australia. Avian Pathology 1982;11:351-359.
Lupo C, Chauvin C, Balaine L, Petetin I, Péraste J, et al. Post mortem condemnation of processed broiler chickens in Western France. Veterinary Record 2008;162:709-713.

McManus JFA, Mowry RW. Staining methods: histologic and histochemical. 3nd ed. London: Hoeber Medical Division Harper \& Row; 1965

Moura MS, Reis DO, Carreon RS, De Araújo LB, Araújo MFC, et al. Causes of post-mortem convictions of turkeys slaughtered at a facility with Federal Inspection Service (SIF) in the state of Minas Gerais, Brazil. Revista Brasileira de Ciência Veterinária 2012;19(1):7-12.

Nazia MKK, Durrani NU, Kamboh AA, Lakho SA, Rind R, et al. Prevalence of septic arthritis caused by Staphylococcus aureus in poultry birds at Tandojam. Journal of Animal Health and Production 2015;3(3):73.

Oliveira AA, Andrade MA, Armendaris PM, Bueno PHS. Main causes of condemnation to the slaughter of poultry in slaughterhouses registered in the Brazilian Federal Inspection Service between 2006 and 2011. Ciência Animal Brasileira 2016;17(1):79-89.

Peton V, Le Loir Y. Staphylococcus aureus in veterinary medicine. Infection, Genetics and Evolution 2014;21:602-615.

Quinn PJ, Markey BK, Carter ME, Donnelly WJ, Leonard, FC. Microbiologia veterinária e doenças infecciosas. Porto Alegre: Artmed; 2015.

Rasheed BY. Isolation and identification of bacteria causing arthritis in chickens. Iraqi Journal of Veterinary Sciences 2011;25(2):93-95.

Reck C, Menin A, Pilati C, Miletti LC. Clinical and anatomo histopathological characteristics of mixed experimental infection by avian Orthoreovirus and Mycoplasma synoviae in broiler chickens.PesquisaVeterinária Brasileira 2012;32(8):687-691.

Tsai SS, Chen LJ, Shih CY, Chang TC, Chiou MT, Chuang KP. Joint lesions in Taiwan native colored broiler chicken with natural and experimental Staphylococcus aureus or S. Cohnii infection. Taiwan Veterinary Journal 2015:41(4):237-244.

Whitehead CC. Bone biology and skeletal disorders in poultry. London: Carfax Publishing; 1992. 